\title{
Sudden onset loss of vision following subarachnoid haemorrhage
}

\author{
Andrew Walkden, ${ }^{1}$ Paul Brennan ${ }^{2}$ \\ ${ }^{1}$ Department of Neurosurgery, NHS Lothian, Edinburgh, UK \\ ${ }^{2}$ Edinburgh Cancer Research Centre, Edinburgh University, Edinburgh, UK
}

Correspondence to Dr Andrew Walkden; andrew.walkden@nhs.net

\section{DESCRIPTION}

A lady in her 50s was transferred to the neurosurgical department with reduced conscious level resulting from subarachnoid haemorrhage. The culpable anterior communicating artery aneurysm was coiled without complication.

The following day she remained drowsy and slightly dysphasic, but intimated a sudden alteration in visual acuity in her right eye. On examination, she was unable to count fingers in the right eye and struggled to see the light of the pen-torch. Right-sided relative afferent pupillary defect was present. No other cranial nerve abnormalities were detected.

Upon examination of her right fundus copious intraretinal and subhyaloid haemorrhage was seen involving the macula area (figures 1 and 2). The left fundus showed some small haemorrhages but visual acuity was unaffected.

The French Ophthalmologist Albert Terson is credited with recognising intraocular haemorrhage occurring in conjunction with subarachnoid haemorrhage; Terson's syndrome. ${ }^{1}$ One systematic review found Vitreous, retinal or subhyaloid haemorrhage to occur in $13 \%$ of patients with subarachnoid haemorrhage. ${ }^{2}$ The pathological mechanism remains unclear although it is thought that raised intracranial pressure forces blood into the subarachnoid space, along the optic nerve sheath and into the preretinal space. The sudden rise in intracranial pressure may also lead to a decrease in venous return to the cavernous sinus or obstruct the retinochoroidal anastomoses and central retinal vein, resulting in venous stasis and haemorrhage.

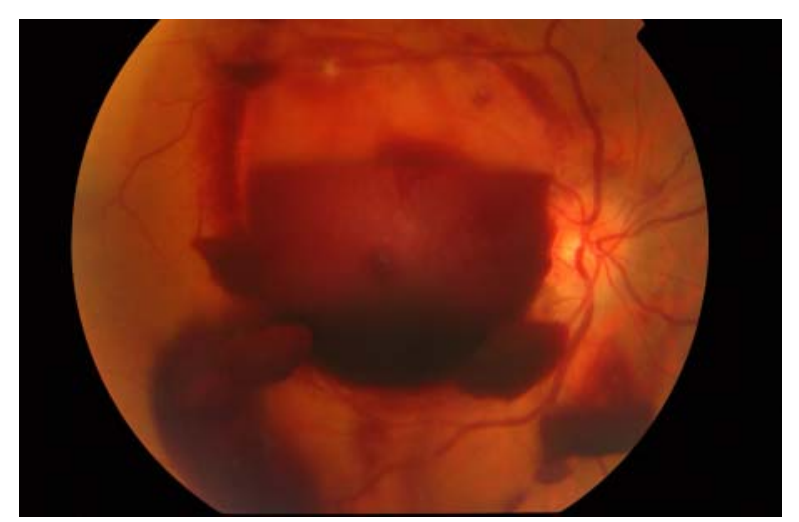

Figure 1 Right fundus showing copious intraretinal and subhyaloid haemorrhages involving the macula area.

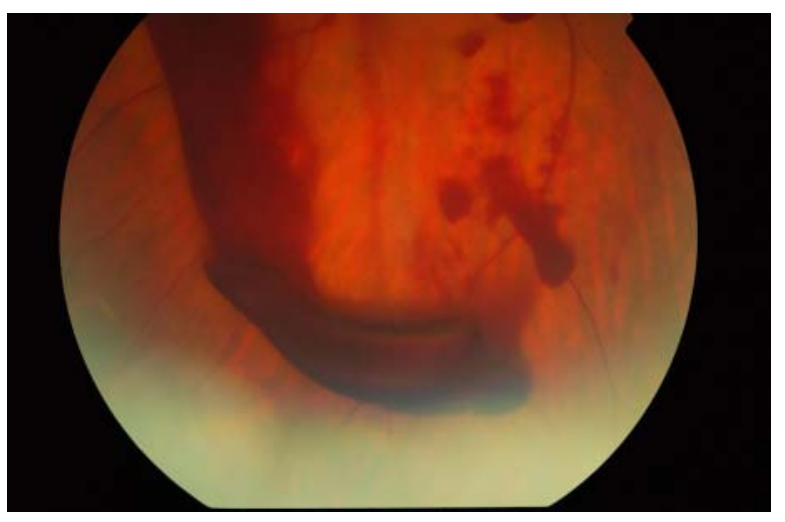

Figure 2 Right fundus showing copious intraretinal and subhyaloid haemorrhages.

Spontaneously clearing vitreous or intraocular haemorrhage is most common. Elevated head positioning with bed rest and witholding anticoagulant medications is important. Larger haemorrhages may require vitrectomy to aid resolution, especially if both eyes are involved.

\section{Learning points}

- Terson's syndrome is an uncommon but potentially sight threatening complication of subarachnoid haemorrhage.

- Fundal examination is essential in all patients presenting with Subarachnoid haemorrhage.

- Ophthalmic referral is necessary in all patients with decreased visual acuity as surgical intervention may be required.

Competing interests None.

Patient consent Obtained.

\section{REFERENCES}

1. Terson A. De l'hémorrhagie dans le corps vitre au cours de l'hémorrhagie cerebrale. Clin Ophthalmol 1900;6:309-12.

2. Fahmy JA. Fundal haemorrhages in ruptured intracranial aneurysms. I. Material, frequency and morphology. Acta Ophthalmol 1973;51:289-98. 


\section{BMJ Case Reports}

This pdf has been created automatically from the final edited text and images.

Copyright 2012 BMJ Publishing Group. All rights reserved. For permission to reuse any of this content visit http://group.bmj.com/group/rights-licensing/permissions.

BMJ Case Report Fellows may re-use this article for personal use and teaching without any further permission.

Please cite this article as follows (you will need to access the article online to obtain the date of publication).

Walkden A, Brennan P. Sudden onset loss of vision following subarachnoid haemorrhage. BMJ Case Reports 2012;10.1136/bcr-2012-006975, Published XXX

Become a Fellow of BMJ Case Reports today and you can:

- Submit as many cases as you like

- Enjoy fast sympathetic peer review and rapid publication of accepted articles

- Access all the published articles

- Re-use any of the published material for personal use and teaching without further permission

For information on Institutional Fellowships contact consortiasales@bmjgroup.com

Visit casereports.bmj.com for more articles like this and to become a Fellow 